\title{
KONTRIBUSI PSIKOLOGI ORANGTUA MURID DALAM PENGELOLAAN LEMBAGA PENDIDIKAN ISLAM: STUDI ANALISIS LAYANAN SDIT BAITUL JANNAH
}

\author{
Esen Pramudya Utama \\ IAI An-Nur Lampung \\ dya_chester@yahoo.com
}

\begin{abstract}
Abstrak
Lembaga pendidikan dan orang tua memiliki peran penting dalam meningkatkan kecerdasan anak-anak. Sekolah adalah tempat kedua bagi anak-anak untuk mendapatkan pengetahuan dan mengembangkan keterampilan. Sekolah yang bagus dan sesuai dengan karakter anak akan mampu membimbing anak-anak menuju masa depan yang lebih baik. Ada banyak faktor yang mempengaruhi persepsi orang tua memilih sekolah yang terdiri dari faktor internal orangtua, internal sekolah atau lingkungan. Penulis ingin melihat faktor-faktor yang mempengaruhi orang tua dalam memilih sekolah berdasarkan indikator internal sekolah. Indikator internal sekolah yang dipertanyakan meliputi: ketepatan, kecermatan dan kecepatan pelayanan, kemampuan dalam menghadapi permasalahan yang timbul, kesediaan dan keterbukaan menerima setiap keluhan, bertanggung jawab atas kualitas produk dan kebijakan penetapan harga yang sesuai, bertangung jawab atas pendidikan agama dan keselamatan, kemudahan dalam memberikan dan menyajikan berbagai informasi, memberikan perhatian khusus kepada anak didik, dan fasilitas serta tata ruang. Penelitian ini bertujuan untuk menyelidiki bagaimana orang tua memilih sekolah untuk anak-anak mereka, terutama mereka yang tinggal di daerah perkotaan. Penelitian ini adalah penelitian lapangan yang dilakukan di SDIT Baitul Jannah dengan deskriptif kualitatif menggunakan quisioner. Hasil penelitian menunjukkan bahwa pandangan masyarakat terhadap lembaga pendidikan Islam secara umum telah mengalami dinamika. Sekolah-sekolah Islam sekarang diasumsikan menjadi tren bagi masyarakat perkotaan dan komunitas kelas menengah atas. Keberadaan sekolah-sekolah Islam dengan sistem sekolah siang penuh adalah untuk memenuhi kebutuhan pendidikan masyarakat perkotaan yang sibuk dan cemas dengan pendidikan agama anakanak mereka.
\end{abstract}

Kata kunci: Persepsi Orangtua, Internal Sekolah, Pendidikan Islam 



\section{PENDAHULUAN}

Memilih sekolah yang tepat untuk anak bukanlah hal yang mudah bagi sebagian orangtua. Berbagai pilihan sekolah pun disuguhkan di depan mata, seperti sekolah unggulan, full day school, Islamic school, sekolah dengan asrama, sekolah bilingual, bahkan kombinasi kategori-kategori tersebut. Umumnya era sekarang, persoalan memilih sekolah bukan lagi tentang biaya dan jarak tempuh seperti yang dilakukan orangtua kita dulu saat kita kecil. Namun juga terhadap pertimbangan pada pembacaan orangtua terhadap fenomana dunia sekarang ini dimana arus globalisasi dan informasi dan akibat penetrasi budaya asing menjadikan moralitas agama menjadi permasalahan krusial, adanya kenakalan remaja, masalah korupsi, budaya hidup hedonis, hilangnya nilai-nilai kemanusiaan, degradasi moral, kejahatan, dan seterusnya, mengharuskan para orangtua dan masyarakat untuk membentengi para generasinya dengan moralitas agama. Lebih-lebih pada kehidupan generasi remaja sekarang yang semakin lama semakin kompleks dan kering akan agama. Masyarakat cenderung memilih lembaga pendidikan berbasis agama khususnya Islam karena mereka yakin akan mendapat ketenangan batin jika anak-anak mereka berada pada lingkungan yang agamis, diikuti dengan aktifitas sehari-hari di sekolah yang selalu didasarkan pada nilai agama. Karena mereka yakin dengan penanaman agama yang kuat pada diri anak sejak dini, mereka tidak akan menjadi anak nakal atau anak yang tidak mentaati peraturan agama.

Bagi orangtua yang berpeluang memilih, mereka akan memilih lembaga pendidikan yang berkualitas. Oleh karena itu, beberapa lembaga pendidikan berlomba membuat branding dan ikon yang marketable agar menjadi pilihan bagi masyarakat, mulai dari tawaran kompetensi, skill, mudah diterima di sekolah lanjut, mudah diterima pekerjaan dengan menjanjikan bahwa setelah peserta didik lulus akan siap untuk menerima tawaran pekerjaan, hingga ikon dan branding bahwa setelah selesai pendidikan di lembaga tersebut peserta didik akan menjadi manusia super, manusia hebat, manusia religi dan lain lain. Untuk melengkapi ikon dan branding, lembaga pendidikan tersebut biasanya dibarengi dengan penawaran fasilitas, mulai dari gedung, profesionalitas tenaga, dan menejemen sekolah, kurikulum yang canggih hingga alumni-alumni yang telah dihasilkan.

Berdasarkan fenomena diatas, dapat disimpulkan bahwa terdapat berbagai permasalahan yang dialami oleh orangtua siswa dalam memilih lembaga pendidikan anak dan harapan terhadap keberadaan lembaga pendidikan dalam kualitas maupun pelayanan. Fenomena tersebut merupakan dampak kebutuhan stakeholder pendidikan, yang mana oleh Manajemen SDIT Baitul 
Jannah Bandar Lampung dijadikan dasar dalam pengelolaan lembaga pendidikannya.

\section{LANDASAN TEORI}

\section{Teori Kebutuhan Maslow}

Memahami kecenderungan orangtua murid ataupun masyarakat akan hadirnya lembaga pendidikan Islam dengan model sekolah Islam, dapat dikaitkan dengan pendapat Abraham Maslow tentang teori kebutuhan. Secara hirarkis, manusia akan berusaha untuk memenuhi kebutuhan-kebutuhannya yang meliputi; kebutuhan fisiologis (physiological needs), kebutuhan keamanaan (safety and security need), kebutuhan sosial (social needs), kebutuhan harga diri (esteem needs), dan kebutuhan aktualisasi diri (self actualization needs). ${ }^{1}$ Secara fisik stakeholder pendidikan membutuhkan lembaga pendidikan dengan kriteria gedung yang bagus, fasilitas yang lengkap, serta sarana dan prasarana yang memadai. Secara safety pun menginginkan lembaga pendidikan yang bisa memberikan rasa aman dan nyaman pada siswa.

Selain itu secara kebutuhan harga diri dan aktualisasi diri, membutuhkan lembaga pendidikan yang dapat memenuhi harapan orangtua dan peserta didik terutama dalam hal keagamaan. Hirarki kebutuhan tersebut dapat digambarkan dengan piramida di bawah ini:

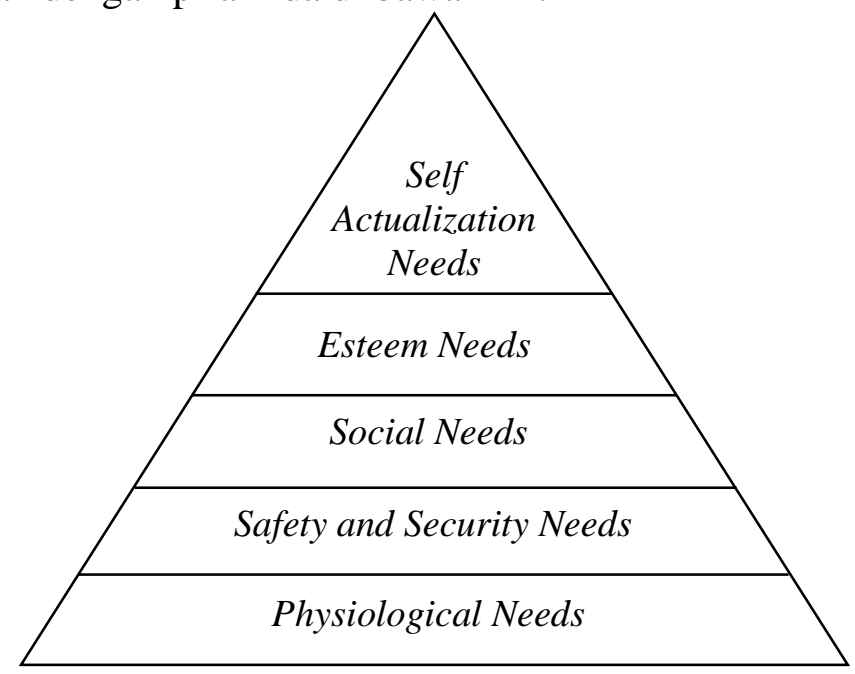

\footnotetext{
1 Sarlito W. Sarwono, Berkenalan dengan Aliran-aliran dan Tokoh-tokoh Psikologi (Jakarta: Bulan Bintang, 2002), h. 176-177.
} 


\section{Konsep Pengambilan Keputusan}

Pengambilan keputusan merupakan tindakan dalam pemilihan alternatif untuk mencapai sasaran. Menurut Kotler $^{2}$ terdapat lima tahap proses pengambilan keputusan. Lima tahap proses pengambilan keputusan tersebut adalah sebagai berikut:

a. Pengenalan kebutuhan, tahap dimana konsumen mengenali permasalahan atau kebutuhan.

b. Pencarian informasi, tahap dimana konsumen tergerak untuk mencari informasi tambahan.

c. Pengevaluasi alternatif, tahap dimana konsumen menggunakan informasi untuk mengevaluasi berbagai merek alternatif di dalam serangkaian pilihan.

d. Keputusan pembelian, tahap dimana konsumen melakukan tindakan lebih lanjut setelah pembelian berdasarkan pada kepuasan atau ketidakpuasan mereka.

e. Pasca pembelian, tahap dimana adanya rasa kepuasan dan ketidakpuasan konsumen terhadap produk yang akan memengaruhi perilaku konsumen selanjutnya.

Secara psikologis keputusan untuk membeli dipengaruhi oleh motivasi, persepsi, proses belajar, kepercayaan dan sikap. Motivasi yaitu sesuatu yang dapat mendorong seseorang melakukan sesuatu, termasuk pembelian. Persepsi merupakan proses dimana seseorang memilih mengorganisasikan, mengartikan masukan informasi untuk menciptakan suatu gambaran yang berarti. Proses belajar menjelaskan perubahan dalam perilaku seseorang yang timbul dari pengalaman. Sedangkan kepercayaan adalah gagasan deskriptif yang dimiliki seseorang terhadap sesuatu.

\section{Kepuasan Layanan}

Dengan mengetahui alasan yang mendasari mengapa konsumen melakukan pembelian, maka dapat diketahui strategi yang tepat untuk digunakan. Dengan kata lain, pihak pemasar harus mengaktualisasikan setiap harapan konsumen menjadi suatu kepuasan atas pelayanan yang diberikan. Di mana hal tersebut merupakan kunci keberhasilan yang menjadikannya berbeda dari pesaingnya. Karena jika tidak demikian maka perusahaan akan ditinggalkan oleh pelanggannya, seperti pendapat yang dikemukakan berikut: "Semakin disadari bahwa pelanggan merupakan aset bagi perusahaan. Dengan pemasaran yang semakin ketat, tanpa memiliki pelanggan tetap, perusahaan dengan mudah mengalami resiko kemunduran dalam bisnisnya. Bahkan lebih

\footnotetext{
${ }^{2}$ Kotler, Philip. 2001. Manajemen Pemasaran. Edisi Pertama. Jakarta: Salemba Empat.
} 
ekstrim lagi perusahaan akan mengalami kerugian yang cukup besar dan ditinggalkan pelanggan". ${ }^{3}$

Perhatian terhadap peningkatan kualitas pelayanan dari waktu ke waktu menjadi semakin penting. Seiring dengan perkembangannya, masyarakat sebagai konsumen tidak lagi bertindak sebagai objek dalam penilaian terhadap kualitas pelayanan, melainkan telah menjadi salah satu subjek penentu dalam menilai akan kualitas pelayanan suatu perusahaan, seperti pandangan dibawah ini: "Banyak penelitian menyatakan, kepuasan pelanggan sering ditentukan oleh kualitas produk atau jasa yang ditawarkan. Dalam konteks jasa, beberapa kepuasan pelanggan digambarkan sebagai suatu antesenden dari kualitas jasa". 4

Dalam hubungan dengan penciptaan nilai kepuasan bagi pelanggan, dimensidimensi yang menjadi fokus pada kualitas pelayanan, antara lain: (1) kehandalan (reliability), sebagai kemampuan perusahaan dalam melaksanakan jasa yang dijanjikan secara tepat dan terpercaya, (2) daya tanggap (responsiveness), yang menunjukkan kemauan untuk membantu pelanggan dan memberikan jasa dengan cepat atau tanggap, (3) jaminan (assurance) menunjukan sejauhmana pengetahuan dan kesopanan karyawan serta kemampuan menciptakan imageatau persepsi yang baik bagi perusahaan, dengan menum-buhkan kepercayaan dan keyakinan dibenak konsumen terhadap perusahaan, (4) empati (empathy), sebagai syarat untuk peduli dan memberikan perhatian secara pribadi bagi pelanggan, dan (5) bukti fisik (tangible) berupa penampilan fasilitas fisik, peralatan, personel, dan media komunikasi. Dimensi-dimensi inilah yang harus diperhatikan oleh produsen, sehingga berbagai pengalaman yang dapat mengakibatkan kegagalan tidak akan terjadi. ${ }^{5}$

Kualitas pelayanan merupakan dasar bagi pemasaran jasa, karena inti produk yang dipasarkan adalah suatu kinerja (yang berkualitas), dan kinerjalah yang dibeli oleh pelanggan, oleh karena itu kualitas kinerja pelayanan merupakan dasar bagi pemasaran jasa. Konsep pelayanan yang baik akan memberikan peluang bagi perusahaan untuk bersaing dalam merebut konsumen.

3 Massie James D., 1998. Menciptakan Kepuasan Pelanggan Melalui Quality Function Deploy-ment (QFD): Alternatif Meraih Keunggulan Operasional Perusahaan Dan Membangun relatioship Marketing. Majalah Efisiensi. Fakultas Ekonomi Universitas Sam Ratulangi.

${ }^{4}$ Bitner Mary Jo., 1990. “Evaluating Service Encoun-ters: The Effectcts of Physical Surroundings and Employee Responses.” Journal of Marketing. Vol. 54 (April, pp. 69-82).

${ }^{5}$ Kotler, Philip. 2000. Marketing Managemet The Millenium Edition.Ten Edition. USA: Prentice-Hall, Inc. 
Sedangkan kinerja yang baik (berkualitas) dari sebuah konsep pelayanan menimbulkan situasi yang kompetitif dimana hal tersebut dapat diimplementasikan melalui strategi untuk meyakinkan pelanggan, memperkuat image tentang merek, iklan, penjualan, dan penentuan harga. Strategi inovator terhadap kualitas layanan biasanya sulit ditiru dibandingkan dengan sekedar konsep layanan itu sendiri. Hal tersebut disebabkan karena kualitas layanan berasal dari kepemimpinan yang terinspirasi melalui organisasi, budaya perusahaan yang berorientasi pada pelanggan, desain sistem layanan prima, penggunaan informasi dan teknologi yang efektif, serta faktor-faktor lainnya yang dikembangkan oleh organisasi.

\section{METODE PENELITIAN}

Penelitian ini merupakan penelitian kualitatif deskriptif yang merupakan salah satu metode yang menggambarkan dengan jelas tentang kondisi objek penelitian dilakukan, serta menggambarkan variabel atau kondisi di lapangan dalam suatu kondisi tertentu. Dalam pelaksanaan penelitian, prosedur pengambilan sampel berdasarkan teknik sampling aksidental (accidental sampling). Sehubungan dengan pelaksanaan penelitian, pengumpulan data dilaksanakan dengan menggunakan kuisioner, merubah data kualitatif menjadi data kuantitatf dengan pengukur data Model Skala Likert.

\section{PEMBAHASAN DAN ANALISIS PELAYANAN}

\section{Aspek Kualitas Layanan}

Dalam penelitian, dimensi kualitas layanan meliputi kehandalan, daya tanggap, jaminan, empati, dan bukti fisik. Kehandalan merupakan kemampuan dalam memberikan layanan secara tepat dan akurat. Dalam pengukurannya didasarkan pada ketepatan dan kecepatan pelayanan, kelengkapan penyediaan dan kemudahan dalam mendapatkan pelayanan. Daya Tanggap merupakan kesediaan dalam membantu wali murid serta tanggap menghadapi setiap permasalahan. Dalam pengukurannya didasarkan pada kemampuan perusahaan dalam menghadapi setiap permasalahan yang timbul, serta sikap ramah dan sopan dari staffnya. Jaminan merupakan kemampuan dalam memberikan kepastian pelayanan sebagai upaya menimbulkan kepercayaan bagi konsumen terhadap sekolah. Dalam pengukurannya didasarkan pada kesesuaian harga dan tanggung jawab atas kualitas penyelengaraan pendidikan, maupun tanggung jawab atas pendidikan keagamaan dan keselamatan konsumen. Empati merupakan kemampuan dalam memberikan perhatian secara pribadi terhadap konsumen sekolah. Dalam pengukuran didasarkan pada kemauan dan kesediaan memberikan perhatian khusus kepada konsumen, maupun kemudahan dalam memberikan dan menyediakan berbagai informasi. Bukti Fisik merupakan kemampuan 
dalam menyediakan dan menampilkan fasilitas fisik, perlengkapan, personil, dan sarana komunikasi. Dalam pengukurannya didasarkan pada kebersihan, kerapian, dan penataan ruangan/fasilitas, tersedianya ruangan atau fasilitas yang representatif, termasuk sarana pendukung.

\section{Analisa Kepentingan Konsumen-Kinerja Sekolah}

Dalam pelaksanaan penelitian, metode ini akan digunakan untuk menganalisis secara deskriptif kualitas jasa, dilihat berdasarkan tingkat kesesuaian antara jasa yang diharapkan (kepentingan konsumen) dengan jasa yang dirasakan (kinerja sekolah). Tingkat kesesuaian yang dimaksud dalam pelaksanan penelitian adalah hasil perbandingan skor nilai jasa yang diharapkan (kepentingan konsumen) dengan skor nilai jasa yang dirasakan (kinerja sekolah). Formula yang digunakan untuk penilaian tingkat kesesuaian adalah:

$$
\mathrm{TK}_{\mathrm{i}}=\frac{\mathrm{X}_{\mathrm{i}}}{\mathrm{Y}_{\mathrm{i}}} \times 100 \%
$$

Keterangan:

$\mathrm{Tk}_{\mathrm{i}}=$ Tingkat kesesuaian

$\mathrm{X}_{\mathrm{i}} \quad$ = Skor penilaian jasa yang dirasakan

$\mathrm{Y}_{\mathrm{i}} \quad=$ Skor penilaian jasa yang diharapan

Untuk sumbu mendatar (X) merupakan skor untuk jasa yang dirasakan, sedangkan untuk sumbu tegak (Y) merupakan skor untuk jasa yang diharapkan. Skor-skor penilaian tersebut akan disederhanakan untuk mendapatkan nilai rata-rata masing-masing faktor. Penyederhanaan masingmasing faktor penilaian tersebut dengan menggunakan formula sebagai berikut:

$X r_{1}=\frac{\sum X_{i}}{n} \quad, \quad Y r_{1}=\frac{\sum Y_{i}}{n}$

Keterangan:

$\mathrm{Xi}=$ Skor penilaian jasa yang dirasakan

$\mathrm{Yi}=$ Skor penilaian jasa yang diharapankan

$\mathrm{Xr}_{1}=$ Skor rata-rata penilaian jasa yang dirasakan

$\mathrm{Yr}_{1}=$ Skor rata-rata penilaian jasa yang diharapkan

$\mathrm{n} \quad=$ Jumlah sampel

Diagram kartesius merupakan suatu bangun yang dibagi atas empat bagian yang dibatasi oleh dua buah baris yang berpotongan pada titik-titik $(\mathrm{X}, \mathrm{Y})$. Untuk $\mathrm{X}$ adalah rata-rata dari rata-rata skor jasa yang dirasakan, dan $\mathrm{Y}$ adalah rata-rata dari rata-rata skor jasa yang diharapkan. Untuk jelasnya rumus yang dimaksud adalah:

$X r_{2}=\frac{\sum N_{i-i} X r_{1}}{K} \quad, Y r_{2}=\frac{\sum N_{i-i} Y r_{1}}{K}$

Keterangan: 
$\mathrm{Xr}_{1}=$ Skor rata-rata penilaian jasa yang dirasakan

$\mathrm{Yr}_{1}=$ Skor rata-rata penilaian jasa yang diharapkan

$\mathrm{Xr}_{2}=$ Rata-rata skor rata-rata penilaian jasa yang dirasakan

$\mathrm{Yr}_{2}=$ Rata-rata skor rata-rata penilaian jasa yang diharapkan

$\mathrm{K}$ = Banyaknya factor

Masing-masing dimensi penilaian baik skor rata-rata penilaian jasa yang dirasakan $(\mathrm{X})$ maupun skor rata-rata penilaian jasa yang diharapkan (Y) dijabarkan ke dalam empat bagian Diagram Kartesius.

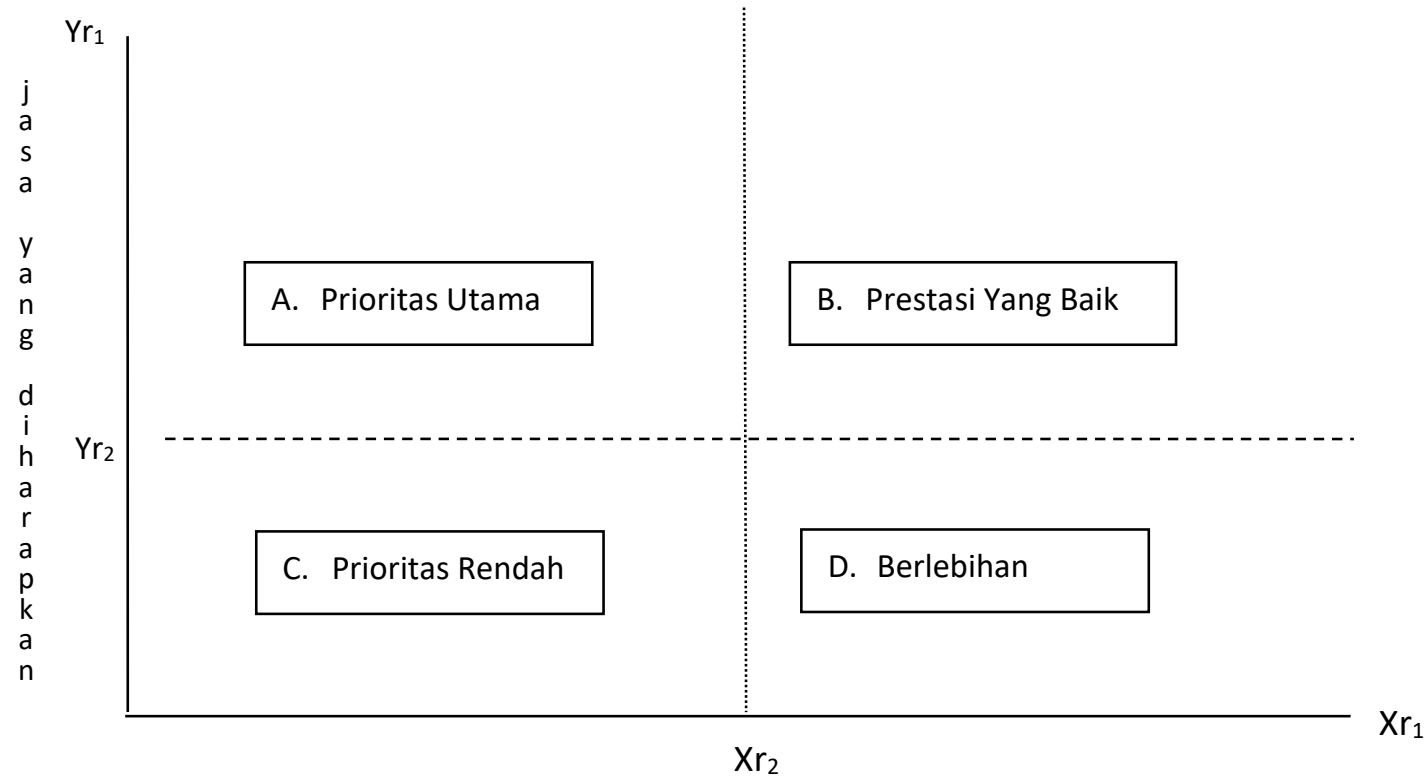

Jasa yang dirasakan

Gambar 1. Diagram Kartesius Analisa Kepentingan-Kinerja Tabel 1.Klasifikasi Responden Berdasarkan Alasan Memilih Tempat Bersekolah Pada SDIT Baitul Jannah

\begin{tabular}{|l|l|c|c|}
\hline \multirow{2}{*}{ No } & \multirow{2}{*}{ Alasan Memilih Tempat } & \multicolumn{2}{|c|}{ Frekuensi } \\
\cline { 3 - 4 } & & $\%$ & Jumlah \\
\hline 1 & Jaminan pendidikan agama & 15 & 15 \\
\hline 2 & Jaminan keselamatan & 15 & 15 \\
\hline 3 & Kelengkapan Fasilitas/Sarana & 15 & 15 \\
\hline 4 & Kompetensi Karyawan & 13 & 13 \\
\hline 5 & Tingkat Harga & 6 & 6 \\
\hline 6 & Kualitas Produk (Lulusan) & 20 & 20 \\
\hline 7 & Lokasi Strategis & 6 & 6 \\
\hline
\end{tabular}


Informasi data menunjukan bahwa pada dasarnya alasan responden memilih tempat bersekolah sebagian besar didasarkan pada faktor kualitas produk (lulusan), jaminan pendidikan agama, jaminan keamanan-keselamatan pengunjung/konsumen.

\section{Deskripsi Masing-Masing Variabel}

Untuk mengukur tingkat kepuasan konsumen, digunakan sebuah daftar pertanyaan (kuisioner). Data yang diperoleh berupa jawaban dari responden terhadap pertanyaan, diubah menjadi data kuantitatif dengan pengukur data Model Skala Likert. Misalnya, sangat puas diberi nilai (5), puas (4), ragu-ratu (3), kurang puas (2), dan tidak puas bernilai (1).

Adapun inti dari daftar pertanyaan dalam penelitian ini berdasarkan pada aspek-aspek sebagai berikut:

a. Penilaian terhadap dimensi kehandalan (reliability), yaitu kemampuan sekolah dalam melaksanakan jasa sesuai dengan yang dijanjikan secara tepat dan terpercaya.

b. Penilaian terhadap dimensi daya tanggap (responsiveness), yaitu kemauan untuk membantu pelanggan dalam memberikan layanan secara cepat dan tanggap.

c. Penilaian terhadap dimensi Jaminan (assurance), yaitu pengetahuan dan kesopanan karyawan serta kemampuan untuk membangun kepercayaan dan keyakinan pelanggan.

d. Penilaian terhadap dimensi empati (emphaty), yaitu kepedulian dan perhatian secara pribadi yang diberikan oleh staf sekolah terhadap pelanggan.

e. Penilaian terhadap dimensi Bukti Fisik (tangible), yaitu penampilan fasilitas fisik, peralatan, personil, dan media komunikasi yang dimiliki sekolah.

\section{Dimensi Kehandalan}

\section{Ketepatan dan Kecermatan serta Kecepatan Pelayanan}

Pada bagian ini diartikan sebagai kesanggupan perusahaan atau pengelola SDIT Baitul Jannah untuk menjamin ketepatan, kecermatan dan kecepatan pelayanan dimasing-masing departemen. Data menunjukan bahwa tanggapan responden sangat mengharapkan agar pihak sekolah memperhatikan atribut kualitas jasa tersebut. Kenyataan ini dibuktikan dengan jumlah responden yang menyatakan Sangat Setuju sebesar 63\%, Setuju sebanyak 37\%. Di satu sisi, tanggapan responden atas kualitas jasa yang dirasakan Sangat Setuju sebanyak 37\%, Setuju sebanyak 50\% dan Ragu-Ragu sebanyak 13\%. Secara keseluruhan rata-rata total rata-rata tanggapan responden Sangat Setuju mengharapkan atribut kualitas jasa tersebut diperhatikan sebesar 4,63. Sedangkan tanggapan atas kualitas jasa yang dirasakan Setuju sebesar 4,23. 


\section{Dimensi Daya Tanggap}

\section{Kemampuan dalam Menghadapi Permasalahan yang Timbul}

Menunjukkan kesediaan dan keterbukaan pihak sekolah, dalam menghadapi berbagai permasalahan yang timbul, seperti terjadi perkelahian. Data menunjukan bahwa tanggapan responden sangat mengharapkan agar pihak sekolah memperhatikan atribut kualitas jasa tersebut. Kenyataan ini dibuktikan dengan jumlah responden yang menyatakan Sangat Setuju sebesar 27\%, Setuju sebesar 70\%, Ragu-Ragu sebesar 3\%. Di satu sisi, tanggapan responden atas kualitas jasa yang dirasakan Sangat Setuju sebesar 55\%, Setuju sebesar 39\% dan Ragu-Ragu sebesar 6\%. Secara keseluruhan rata-rata total rata-rata tanggapan responden Setuju mengharapkan atribut kualitas jasa tersebut diperhatikan sebesar 4,23. Sedangkan tanggapan atas kualitas jasa yang dirasakan Sangat Setuju sebesar 4,53.

\section{Ketersediaan dan Keterbukaan dalam Menerima Setiap Keluhan}

Pada faktor ini sekolah dituntut untuk tanggap terhadap setiap keluhan yang disampaikan. Suatu masalah yang diantisipasi dengan cepat oleh pihak sekolah, memberikan suatu kesan yang baik pada konsumen, sehingga dapat mengurangi kekecewaan. Data menunjukan bahwa tanggapan responden sangat mengharapkan agar pihak sekolah memperhatikan atribut kualitas jasa tersebut. Kenyataan ini dibuktikan dengan jumlah responden yang menyatakan Sangat Setuju sebesar 30\%, Setuju sebesar 67\%, Ragu-Ragu sebesar 3\%. Di satu sisi, tanggapan responden atas kualitas jasa yang dirasakan Sangat Setuju sebesar 37\%, Setuju sebesar 60\% dan Ragu-Ragu sebesar 3\%. Secara keseluruhan rata-rata total rata-rata tanggapan responden Setuju mengharapkan atribut kualitas jasa tersebut diperhatikan sebesar 4,27.Sedangkan tanggapan atas kualitas jasa yang dirasakan Setuju sebesar 4,33 .

\section{Dimensi Jaminan}

\section{Tanggung Jawab atas Kualitas Produk (Lulusan) dan Penetapan Harga}

Menunjukkan kemampuan sekolah dalam meyakinkan konsumen atas tanggung jawab sekolah terhadap kualitas produk dari penyelenggaraan pendidikan, serta kebijakan sekolah dalam hal penetapan harga. Data menunjukan bahwa tanggapan responden sangat mengharapkan agar pihak sekolah memperhatikan atribut kualitas jasa tersebut. Kenyataan ini dibuktikan dengan jumlah responden yang menyatakan Sangat Setuju sebesar $53 \%$, Setuju sebesar $47 \%$. Di satu sisi, tanggapan responden atas kualitas jasa yang dirasakan Sangat Setuju sebesar 33\%, Setuju sebesar 67\%. Secara keseluruhan rata-rata total rata-rata tanggapan responden Sangat Setuju 
mengharapkan atribut kualitas jasa tersebut diperhatikan sebesar 4,53.Sedangkan tanggapan atas kualitas jasa yang dirasakan Setuju sebesar 4,33 .

\section{Tanggung Jawab Atas Pendidikan Agama Dan Keselamatan Konsumen}

Menunjukkan tanggung jawab atas pendidikan agama dan keselamatan pengunjung dan konsumen. Hal ini diwujudkan sekolah dengan menempatkan sekuriti pada tempat-tempat tertentu. Data menunjukan bahwa tanggapan responden sangat mengharapkan agar pihak sekolah memperhatikan atribut kualitas jasa tersebut. Kenyataan ini dibuktikan dengan jumlah responden yang menyatakan Sangat Setuju sebesar 53\%, Setuju sebesar $47 \%$. Di satu sisi, tanggapan responden atas kualitas jasa yang dirasakan Sangat Setuju sebesar 41\%, Setuju sebesar 56\% dan Ragu-Ragu sebesar 3\%. Secara keseluruhan rata-rata total rata-rata tanggapan responden Sangat Setuju mengharapkan atribut kualitas jasa tersebut diperhatikan sebesar 4,53. Sedangkan tanggapan atas kualitas jasa yang dirasakan Setuju sebesar 4,37.

\section{Dimensi Empati}

\section{Kemudahan Dalam Memberikan dan Menyajikan Berbagai Informasi}

Menunjukkan kemampuan sekolah dalam menyajikan dan menyediakan berbagai informasi, baik melalui karyawan secara langsung maupun melalui media-media promosi yang tersedia. Data menunjukan bahwa tanggapan responden sangat mengharapkan agar pihak sekolah memperhatikan atribut kualitas jasa tersebut. Kenyataan ini dibuktikan dengan jumlah responden yang menyatakan Sangat Setuju sebesar 23\%, Setuju sebesar 77\%. Di satu sisi, tanggapan responden atas kualitas jasa yang dirasakan Sangat Setuju sebesar 31\%, Setuju sebesar 63\% dan Ragu-Ragu sebesar 6\%. Secara keseluruhan rata-rata total rata-rata tanggapan responden Setuju mengharapkan atribut kualitas jasa tersebut diperhatikan sebesar 4,27. Sedangkan tanggapan atas kualitas jasa yang dirasakan Setuju sebesar 4,20.

\section{Perhatian Khusus Kepada Pengunjung/Konsumen}

Menunjukkan kemampuan sekolah dalam memberikan perhatian khusus bagi konsumen, dengan tujuan untuk mempertahankan loyalitas konsumen. Data menunjukan bahwa tanggapan responden sangat mengharapkan agar pihak perusahaan memperhatikan atribut kualitas jasa tersebut. Kenyataan ini dibuktikan dengan jumlah responden yang menyatakan Sangat Setuju sebesar 27\%, Setuju sebesar $73 \%$. Di satu sisi, tanggapan responden atas kualitas jasa yang dirasakan Sangat Setuju sebesar 27\%, Setuju sebesar 73\%. Secara keseluruhan rata-rata total rata-rata tanggapan responden Setuju 
mengharapkan atribut kualitas jasa tersebut diperhatikan sebesar 4,23. Sedangkan tanggapan atas kualitas jasa yang dirasakan Setuju sebesar 4,23.

\section{Dimensi Bukti Fisik}

\section{Kebersihan, Kerapian dan Penataan Ruangan/Fasilitas}

Kebersihan dan kerapian serta penataan ruangan/fasilitas merupakan salah satu faktor yang paling mudah untuk dinilai oleh konsumen. Untuk menjaga tingkat kebersihan dan kerapian diperlukan jasa cleaning service, yang bertugas untuk membersihkan dan merapikan ruangan beserta fasilitas didalamnya. Data menunjukan bahwa tanggapan responden sangat mengharapkan agar pihak sekolah memperhatikan atribut kualitas jasa tersebut. Kenyataan ini dibuktikan dengan jumlah responden yang menyatakan Sangat Setuju sebesar 63\%, Setuju sebesar 37\%. Di satu sisi, tanggapan responden atas kualitas jasa yang dirasakan Sangat Setuju sebesar 20\%, Setuju sebesar 57\% dan Ragu-Ragu sebesar 23\%. Secara keseluruhan rata-rata total rata-rata tanggapan responden Sangat Setuju mengharapkan atribut kualitas jasa tersebut diperhatikan sebesar 4,63. Sedangkan tanggapan atas kualitas jasa yang dirasakan Setuju sebesar 3,97.

\section{Tersedianya Sarana Pendukung}

Menunjukkan ketersediaan berbagai sarana pendukung, seperti penyediaan peralatan modern, alat hitung, scanner, AC, dan parkir. Data menunjukan bahwa tanggapan responden sangat mengharapkan agar pihak sekolah memperhatikan atribut kualitas jasa tersebut. Kenyataan ini dibuktikan dengan jumlah responden yang menyatakan Sangat Setuju sebesar 63\%, Setuju sebesar $37 \%$. Di satu sisi, tanggapan responden atas kualitas jasa yang dirasakan Sangat Setuju sebesar 16\%, Setuju sebesar 57\% dan Ragu-Ragu sebesar $27 \%$. Secara keseluruhan rata-rata total rata-rata tanggapan responden Sangat Setuju mengharapkan atribut kualitas jasa tersebut diperhatikan sebesar 4,63. Sedangkan tanggapan atas kualitas jasa yang dirasakan Setuju sebesar 3,90. 
Tabel 2. Total Rata-Rata Tanggapan Responden Terhadap Jasa yang Diharapkan dengan Jasa yang Dirasakan

\begin{tabular}{|c|c|c|c|}
\hline \multirow{2}{*}{ No } & \multirow{2}{*}{ Dimensi Penelitian } & \multicolumn{2}{|c|}{ Jasa / Service } \\
\hline & & Diharapkan & Dirasakan \\
\hline 1 & $\begin{array}{l}\text { Ketepatan, kecermatan dan kecepatan dalam } \\
\text { pelayanan }\end{array}$ & $139(4.63)$ & $127(4.23)$ \\
\hline 2 & Kemampuan menghadapi permasalahan yang timbul & $127(4.23)$ & $136(4.53)$ \\
\hline 3 & Kesediaan dan keterbukaan menerima setiap keluhan & $128(4.27)$ & $130(4.33)$ \\
\hline 4 & $\begin{array}{l}\text { Bertanggung jawab atas kualitas produk dan kebijakan } \\
\text { penetapan harga yang sesuai }\end{array}$ & $136(4.53)$ & $130(4.33)$ \\
\hline 5 & $\begin{array}{l}\text { Bertangung jawab atas pendidikan agama dan } \\
\text { keselamatan }\end{array}$ & $136(4.53)$ & $131(4.37)$ \\
\hline 6 & $\begin{array}{l}\text { Kemudahan dalam memberikan dan menyajikan } \\
\text { berbagai informasi }\end{array}$ & $128(4.27)$ & $126(4.20)$ \\
\hline 7 & Memberikan perhatian khusus kepada anak didik & $127(4.23)$ & $127(4.23)$ \\
\hline 8 & Kebersihan, kerapian dan penataan ruangan/ fasilitas & $139(4.63)$ & $119(3.97)$ \\
\hline 9 & $\begin{array}{l}\text { Tersedianya sarana pendukung (Parkir, AC, alat } \\
\text { hitung/scanner, dan lain-lain) }\end{array}$ & $139(4.63)$ & $117(3.90)$ \\
\hline & Rata-rata & 4.48 & 4.27 \\
\hline
\end{tabular}

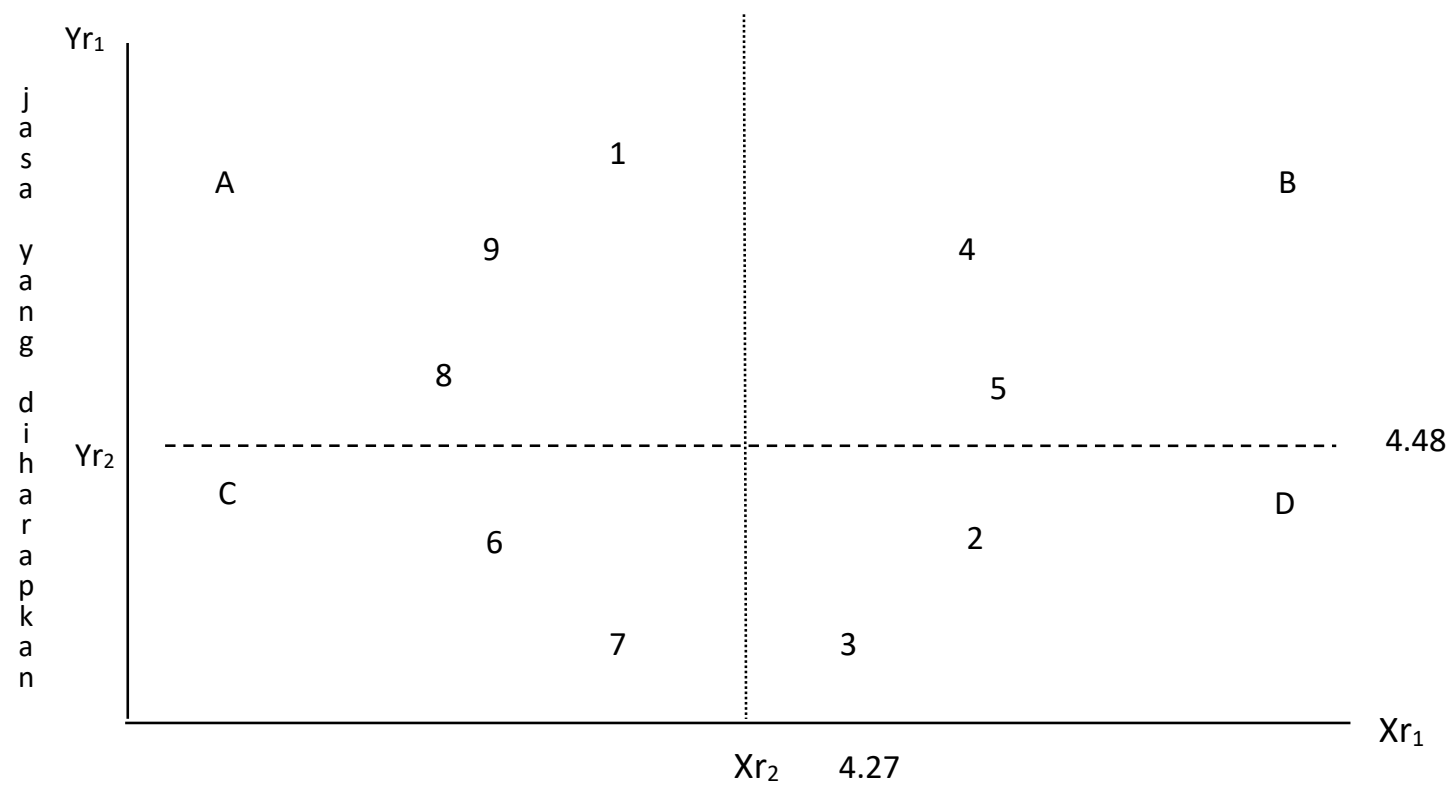

Jasa yang dirasakan

\section{Gambar 2.Diagram Kartesius Dimensi Jasa yang Diharapakan dan Jasa yang Dirasakan Pengunjung/Konsumen SDIT Baitul Jannah}


Pada Gambar 2. Diagram Kartesius, terlihat bahwa letak dari atribut-atribut yang merupakan gambaran penilaian jasa yang diharapkan dan jasa yang dirasakan konsumen SDIT Baitul Jannah.

a. Kuadran A, menunjukkan atribut-atribut yang mempengaruhi kepuasan konsumen, namun pihak SDIT Baitul Jannah belum mampu melaksanakannya dengan baik, meliputi:

- Ketepatan, kecermatan dan kecepatan pelayanan (1).

- Kebersihan, kerapian dan penataan ruangan/fasilitas (8).

- Tersedianya sarana pendukung (9).

b. Kuadran B, menunjukkan atribut yang mempengaruhi kepuasan konsumen, SDIT Baitul Jannah telah melaksanakan sesuai dengan harapan konsumen, antara lain:

- Tanggung jawab atas kualitas produk dan penetapan harga (4).

- Tanggung jawab pendidikan agama dan keselamatan pengunjung maupun konsumen (5).

c. Kuadran C, menunjukkan bahwa atribut yang berada pada kuadran ini, dianggap kurang penting oleh konsumen. Sedangkan kualitas pelayanan yang diberikan SDIT Baitul Jannah tergolong cukup. Atribut-atribut yang termasuk pada kuadran $\mathrm{C}$, antara lain:

- Kemudahan dalam memberikan dan menyajikan informasi (6).

- Pemberian perhatian khusus kepada pengunjung/konsumen (7).

d. Kuadran D, menunjukkan bahwa atribut yang berada pada kuadran ini dianggap kurang penting oleh konsumen, namun kualitas pelayanan yang diberikan SDIT Baitul Jannah sangat baik.

- Kesediaan dan keterbukaan dalam menerima setiap keluhan (3).

- Kemampuan dalam menghadapi permasalahan (2).

\section{SIMPULAN}

Dalam menyikapi minat dan animo calon peserta didiknya, lembaga pendidikan telah melakukan standar prosedur pengembangan kualitas SDIT Baitul Jannah berkelanjutan. Berbagai uji variabel yang mempengaruhi kepuasan konsumen telah dilakukan, diperoleh hasil sebagai berikut: SDIT Baitul Jannah belum mampu melaksanakannya dengan baik, meliputi: Ketepatan, kecermatan dan kecepatan pelayanan; Kebersihan, kerapian dan penataan ruangan/fasilitas; Tersedianya sarana pendukung. SDIT Baitul Jannah telah melaksanakan sesuai dengan harapan konsumen, antara lain: Tanggung jawab atas kualitas produk dan penetapan harga, Tanggung jawab pendidikan agama dan keselamatan pengunjung maupun konsumen. Kualitas pelayanan yang diberikan SDIT Baitul Jannah tergolong cukup, antara lain: Kemudahan dalam memberikan dan menyajikan informasi, Pemberian 
perhatian khusus kepada pengunjung/konsumen. Kualitas pelayanan yang diberikan SDIT Baitul Jannah sangat baik, antara lain: Kesediaan dan keterbukaan dalam menerima setiap keluhan, Kemampuan dalam menghadapi permasalahan. 


\section{DAFTAR PUSTAKA}

Bitner Mary Jo., 1990. "Evaluating Service Encoun-ters: The Effectcts of Physical Surroundings and Employee Responses." Journal of Marketing. Vol. 54 (April, pp. 69-82).

Kotler, Philip. 2000. Marketing Managemet The Millenium Edition.Ten Edition. USA: Prentice-Hall, Inc.

Kotler, Philip. 2001. Manajemen Pemasaran. Edisi Pertama. Jakarta: Salemba Empat.

Massie James D., 1998. Menciptakan Kepuasan Pelanggan Melalui Quality Function Deploy-ment (QFD): Alternatif Meraih Keunggulan Operasional Perusahaan Dan Membangun relatioship Marketing. Majalah Efisiensi. Fakultas Ekonomi Universitas Sam Ratulangi.

Sarlito W. Sarwono, 2001. Berkenalan dengan Aliran-aliran dan Tokohtokoh Psikologi, Jakarta: Bulan Bintang 